\title{
Approach to the evaluation of manufacturing and economic feasibility of technical systems based on real options modeling
}

\author{
Pavel Drogovoz ${ }^{1}$, Olga Yusufova ${ }^{2}$, Alexander Gutenev ${ }^{3}$ \\ ${ }^{l}$ Head of Department «Entrepreneurship and Foreign Economic Activities», D.Sc (Econ), Professor, \\ Bauman University, Moscow; \\ ${ }^{2}$ Assistant Professor of Department «Entrepreneurship and Foreign Economic Activities», Cand.Sc \\ (Econ), Bauman University, Moscow; \\ ${ }^{3}$ Assistant of the Department «Entrepreneurship and Foreign Economic Activities», Bauman \\ University, Moscow.
}

\begin{abstract}
The features of the application of the system engineering methodology, technology and manufacturing readiness levels metrics when creating high-tech industrial products in the digital transformation of the economy are considered. The concept of manufacturing and economic feasibility of a perspective technical system is introduced. An approach to the economic and mathematical modeling of real options is proposed for a formalized description and decision support for managing multi-stage and interconnected processes for creating a goal technical system and supporting manufacturing system. The directions of further research are determined and the tasks of applied development of real options pricing models are posed.

Keywords: system engineering, manufacturing feasibility, economic feasibility, perspective technical system, technology readiness level, manufacturing readiness level, real options valuation.
\end{abstract}

The digital transformation of the economy creates the background for the emergence of technical systems with fundamentally new properties that are propelled by the industrial implementation of artificial intelligence technologies, cloud computing, sensors, virtual and augmented reality. Manufacturing and logistics systems that provide support for the life cycle of promising technical systems are also becoming active components of a single network of intelligent machines that operate on the basis of Industrial Internet technologies. The concept of digital manufacturing is being implemented, and within this framework the "digital twin" of the product is designed, assembled and tested in a virtual environment. It is obvious, that such a transformation means transferring the solution of most of the engineering and economic problems to the initial stages of the product life cycle. This significantly changes the business models and schemes for the formation of scientific and manufacturing cooperation and determines the need for modernization of the methods used to evaluate the manufacturing and economic feasibility of promising technical systems.

In world practice, the main approach to managing the development and manufacturing of high-tech industrial products is the use of an interdisciplinary methodology of systems engineering. In modern management practice, it is implemented as a set of proven methods 
that are widely used as standard managerial decisions abroad in government bodies and in large companies in the aerospace, defense, energy and other industrial sectors: United State Department of Defense (US DoD), United State Department of Energy (US DoE), NASA, EADS, Lockheed-Martin, ESA, Northrop Grumman etc. [1]. In Russia, the development of national standards in this field [2,3] is carried out by the National Research Center "Zhukovsky Institute".

According to GOST R 57194.1-2016 [2], a distinction is made between the target technical system and the supporting system that promotes it throughout the life cycle, while system engineering methods ensure their joint and coordinated creation and subsequent operation in a certain external environment. The most important support system in high technology industries is a manufacturing system that has its own life cycle. The appropriate methodology for evaluation of the maturity of technologies and systems is defined in the GOST R 58048-2017 standard [3]. It provides a systematic evaluation of the achieved levels of technology readiness and allows at an early stage to identify and reduce risks associated with non-fulfillment of relevant projects and programs in time and exceeding the budget allocated for their implementation. The methodology uses the concept of technology maturity, which characterizes their advancement along the life cycle from concept to application. Maturity evaluation is carried out using formalized scales to evaluate technology readiness levels (TRLs), manufacturing readiness levels (MRLs), integration readiness levels (IRLs) and system readiness levels (SRLs). Considering the achieved readiness levels, they decide on the possibility and expediency of transferring specific technologies, further continuing R\&D and shifting technology to the next stage of the life cycle.

In a system engineering methodology, technology (TRLs) and manufacturing (MRLs) readiness levels are key interdependent metrics that measure the degree of risk associated with the maturity of a technology and manufacturing process. The TRL scale contains 9 maturity levels, and the MRL scale contains 10 levels harmonized with them. In general, the manufacturing readiness is determined by the readiness of technology and the stability of the target technical system design (architecture, components, modules, interfaces and data) under conditions of its use [3]. It should be noted that from the standpoint of the recommended tools for evaluation of the manufacturing readiness, the GOST R 58048-2017 standard is limited to the recommendations on the use of questionnaires for the analysis in nine areas: the technological production basis; maturity and stability of the target technical system design; production financing limits; availability of raw stock, materials and components; process management; quality management; the availability of staff competencies; the availability of manufacturing capacities; level of integration of the production management system [3]. Thus, the existing methodological apparatus is based on expert and analytical procedures, which are characterized by a significant degree of subjectivity and the dependence of the final evaluations on the experience and competencies of the experts performing the examination. Moreover, the interviewing and using questionnaires is associated with the obviously incompleteness, inaccuracy and inconsistency of the linguistic information that is used to evaluate readiness levels.

The objective of this paper is the conceptual development of a formalized approach based on rigorous economic and mathematical modeling that allow to avoid problematic situations caused by traditional expert analytical methods. The hypothesis is that the processes of joint creation of the target technical system and the manufacturing system supporting it can be represented in the form of a certain structure of economic and mathematical models of real options valuation (ROV).

To state the essence of the approach, we introduce a number of key concepts and terms. By a promising technical system, we shall understand a target technical system focused on the forecasted or expected needs of real or potential consumers. A distinctive feature of such a system is a high degree of risk of its creation, as a result of which the traditional methods 
of NPV analysis of investments are limited or not applicable at all, since they yield obviously negative results [4]. By the manufacturing and economic feasibility of a promising technical system, we shall understand the integral characteristic that reflects the possibility of manufacturing its copies in accordance with planned terms and volumes, with a given quality level, based on available investment resources and the required rate of return, taking into account key macroeconomic parameters [5]. Generalities on the use of option pricing models for evaluating investment projects and making decisions on the value-based management of an innovative enterprise are given in monographs $[6,7]$. The results of a comparative analysis of the Black-Scholes continuous model and the Cox-Ross-Rubinstein discrete model for real options valuation in industry investment projects are given in [8].

A distinction should be made between financial option models, which are derivative financial instruments for the exchange trading of high-risk stocks, and real option models, which are obtained by transferring the developed financial mathematical models to the tasks of valuating high-risk investments in the real economy. A financial purchase option, or a call option, is a security that gives the right, but not the obligation, to purchase a share at a predetermined price before or at a certain date. A financial sell option, or a put option, gives a similar right to sell a share. A financial option has a fixed maximum period of validity (time to maturity, time to expiration), and an option obligation is exercised according to a fixed exercise price (strike price). There are European option and American option. Under an American option, the asset purchase or sale can be carried out at any time during the period of validity, and under a European option only at the time to expiration [7].

In the real economy, a call option is an option to expand, which allows to evaluate the additional possibilities of commercializing the developed technologies and expanding production as a result of the positive development of the economic situation. Accordingly, a put option is implemented as an option to abandon, which reflects the possibility of early termination of development and completion of an unprofitable project in the case of a negative economic result.

To evaluate the manufacturing and economic feasibility of promising technical systems, a modified Black-Scholes model $[9,10]$ can be used, in which maturity $\left(k_{m}\right)$ and universality $\left(k_{u}\right)$ coefficients of scientific and technical groundwork are introduced and methods for calculating asset prices $(A)$ and strike prices $(X)$ are determined:

$$
\begin{gathered}
C=A \cdot N\left(d_{1}\right)-X \cdot e^{-r_{f}(T-t)} \cdot N\left(d_{2}\right) ; \quad P=X \cdot e^{-r_{f}(T-t)} \cdot N\left(-d_{2}\right)-A \cdot N\left(-d_{1}\right) ; \\
A=\left(1+r_{e}\right) I ; \quad X=k_{m} I ; \quad k_{m}=\left(\frac{L}{L_{\max }}\right)^{e} ; \quad k_{u}=\sum_{i} w_{i} E_{i} ; \\
d_{1}=\frac{\ln \left(\frac{A}{X}\right)+\frac{r_{f}+\sigma^{2}}{2} t}{\sigma \sqrt{t}} ; d_{2}=d_{1}-\sigma \sqrt{t}
\end{gathered}
$$

where $C$ is the value of option to expand; $P$ is the value of option to abandon; $A$ is the asset price as a financial result from investments $I$ in a technology development project at a profitability rate of $r_{e} ; X$ is the strike price of the option, reflecting the exponential increase in the technology market value as its readiness level $L$ approaches the maximum value $L_{\max } ; w_{i}$ is the weight of $i$-th technology application area; $E_{i} \in[0,1]$ is the valuation of the result applicability in the $i$-th area; $\sigma$ is the asset price volatility depending on the patent concentration in the industry under consideration; $N(d, \mu, D)$ is the normal Laplace-Gauss distribution of $d$ with mathematical expectation $\mu=k_{u}$ and variance $D=1 ; r_{f}$ is the risk-free discount rate; $t$ is the calculation period.

In the context of the system engineering methodology, formula (1) is an economic valuation of the feasibility and advisability of shifting technology to the next stage of the life cycle. Accordingly, when describing a multi-stage process of technology advancement by maturity levels, one should use economic and mathematical models of compound options. 
The Geske model [11], obtained for evaluation of a two-stage European call option, and also fuzzy set modifications [12] of this model, are known.

Another key point of system engineering is a joint review of the processes of creating the target technical system and its supporting manufacturing system, and the economic effect is achieved only if the development of both systems is successfully completed and they reach the upper levels of readiness. From the perspective of valuating real options, these processes can be modeled using rainbow options, which contain two or more underlying assets and are exercised when all of these assets are utilized appropriately [13].

The direction for further research on the issue under consideration is to solve the problems of determining a number of key parameters in formula (1) - developing methods for prospective patent analysis [14] to evaluate the maturity of the scientific and technical groundwork and patent concentration; development of methods for exploratory neural network analysis [15] to evaluate the universality of technologies, as well as the subsequent applied development of economic and mathematical models of compound and rainbow options in relation to the specifics of multi-stage and interconnected processes for creating a promising target technical system and its supporting manufacturing system.

\section{References}

1. Gutenev A V 2019 Assessment of the industrial feasibility of R\&D results on the creation of promising aviation systems [Otsenka promyshlennoy realizuyemosti rezul'tatov NIOKR po sozdaniyu perspektivnykh aviatsionnykh kompleksov] Proc. VIII All-Russian Scientific Conference on the organization of production, Bauman Moscow State Technical University, Dec 7-8 2018 (Moscow: REC "Controlling and Management Innovation") 34-44

2. GOST R 57194.1-2016 2016 Technology transfer. General Provisions [Transfer tekhnologiĭ. Obshchiye polozheniya] (Moscow: Standardinform) 12 p.

3. GOST R 58048-2017 2018 Technology transfer. Guidelines for technology maturity evaluation [Transfer tekhnologir. Metodicheskiye ukazaniya po otsenke urovnya zrelosti tekhnologiy] (Moscow: Standardinform) 41 p.

4. Drogovoz P A 2007 Economic and mathematical modeling of innovative projects based on the theory of real options [Ekonomiko-matematicheskoye modelirovaniye innovatsionnykh proyektov na osnove teorii real'nykh optsionov] Herald of the Bauman Moscow State Technical University Ser. Natural Sciences 3 (26) 119-23

5. Yusufova O M 2019 Justification of the composition of the planning and economic parameters of $R \& D$ in the creation of innovative products [Obosnovaniye sostava planovo-ekonomicheskikh parametrov NIOKR pri sozdanii innovatsionnoy produktsii] Proc. XLIII All-Russian Academic Space Conference dedicated to the memory of academician Korolev S.P. and other prominent Russian scientists, Bauman Moscow State Technical University (Moscow: BMSTU Publishing House) 1 176-8

6. Limitovskiy M A 2008 Investment projects and real options in emerging markets [Investitsionnyye proyekty i real'nyye optsiony na razvivayushchikhsya rynkakh] (Moscow: Urait) $464 \mathrm{p}$.

7. Drogovoz P A 2007 Innovative industrial enterprise total cost management: Monograph (Moscow: BMSTU Publishing House) 240 p.

8. Gutenev A V, Kochkin I A and Stepanov A V 2019 Comparative analysis of the use of Black-Scholes and Cox-Ross-Rubinstein models for evaluating real options in industry investment projects [Sravnitel'nyy analiz primeneniya modeley Bleka-Shoulza i KoksaRossa-Rubinshteyna dlya otsenki real'nykh optsionov v investitsionnykh proyektakh $\mathrm{v}$ promyshlennosti] Journal of Economy and entrepreneurship 4 535-43 
9. Black F and Scholes M S 1972 The valuation of option contracts and a test of market efficiency Journal of Finance 27 (2) 399-418

10. Black F and Scholes M S 1973 The pricing of options and corporate liabilities Journal of Political Economy 81 (3) 637-54

11. Geske R 1979 The valuation of compound options Journal of Financial Economics 7 (1) 63-81

12. Baranov A O, Muzyko Ye I and Pavlov V N 2018 Synthesis of the real options method and the fuzzy set method for valuation the effectiveness of innovative projects: a critical review [Sintez metoda real'nykh optsionov i metoda nechetkikh mnozhestv dlya otsenki effektivnosti innovatsionnykh proyektov: kriticheskiı̌ obzor] Ideas and ideals no. 1 vol. 2 190-209

13. Ouwehand $\mathrm{P}$ and West $\mathrm{G}$ Pricing Rainbow Options Wilmott magazine https://wilmott.com/pricing-rainbow-options-wilmott-magazine-article-peterouwehand-graeme-west/

14. Drogovoz P A and Kashevarova N A 2017 The mechanism of promising patent research in the creation of special-purpose space products in the conditions of civil-military integration [Mekhanizm perspektivnykh patentnykh issledovaniy pri sozdanii kosmicheskoy produktsii spetsial'nogo naznacheniya $\mathrm{v}$ usloviyakh voyennograzhdanskoy integratsii] Audit and Financial Analysis 3-4 461-70

15. Shiboldenkov V A 2018 Toolkit of neural network exploratory analysis of socioeconomic processes [Instrumentariy neyrosetevogo razvedochnogo analiza sotsial'noekonomicheskikh protsessov] Audit and Financial Analysis 6 214-24 